\title{
AS REPERCUSSÕES DA EDIÇÃO GENÉTICA EM HUMANOS A PARTIR DA TÉCNICA “CRISPR-CAS9”
}

\section{REVISÃO INTEGRATIVA}

SILVA, Poliane Cardoso da ${ }^{1}$, MORAIS, Lauandecy Maria Domingas Costa $\mathrm{de}^{2}$, LEAL, Kamila Soares ${ }^{3}$

SILVA, Poliane Cardoso da. MORAIS, Lauandecy Maria Domingas Costa de. LEAL, Kamila Soares. As repercussões da edição genética em humanos a partir da técnica "CRISPR-CAS9". Revista Científica Multidisciplinar Núcleo do Conhecimento. Ano 06, Ed. 09, Vol. 05, pp. 85-107. Setembro de 2021. ISSN: 24480959, Link de acesso: https://www.nucleodoconhecimento.com.br/lei/crispr-cas9, DOI: 10.32749/nucleodoconhecimento.com.br/lei/crispr-cas9

\section{RESUMO}

A edição genética através do sistema CRISPR-Cas9 possibilitou grandes avanços no campo da engenharia genética, inclusive, a capacidade de modificar geneticamente embriões humanos com potencial reprodutivo, o que veio a ocorrer recentemente na China. Assim, muitas controvérsias surgem a respeito do tema que suscita dilemas científicos, éticos e legais, problema que norteou o presente estudo com o seguinte questionamento: Quais as principais, repercussões científicas, éticas e legais oriundas da edição genética em humanos através da aplicação da técnica CRISPR-Cas9? Assim, objetivou-se investigar tais impactos a fim de tecer as devidas reflexões acerca do assunto no cenário atual, considerando a proteção ao patrimônio genético em decorrência do princípio da dignidade da pessoa humana. Buscou-se ainda abordar tais aspectos de maneira interdisciplinar, de modo a suscitar o direito conforme perspectivas antropocêntricas. Para realização do estudo utilizou-se de pesquisa teórico-bibliográfica integrativa e documental,

\footnotetext{
${ }^{1}$ Acadêmica do curso de Bacharelado em Direito. ORCID: https://orcid.org/0000-0002-0096-7153

2 Bacharelanda em Direito. ORCID: https://orcid.org/0000-0001-7902-079X

${ }^{3}$ Orientadora.
}

RC: 97449

Disponível em: https://www.nucleodoconhecimento.com.br/lei/crispr-cas9 
operacionalizada através da busca de trabalhos acadêmicos em indexadores nacionais e internacionais, sites oficiais de consulta à legislação, bem como livros atualizados, disponíveis no meio físico e digital. Obteve-se que o sistema CRISPRCas9 é extremamente promissor considerando suas aplicações para terapia gênica, todavia, a aplicação da edição genética nas células reprodutivas humanas encontrase em meio à incertezas científicas com resultados inesperados, a exemplo do mosaicismo e mutações aleatórias; em relação às questões normativas, existe proteção nacional e internacional ao patrimônio genético no que tange às células embrionárias humanas, pois considera-se o DNA humano como um bem inerente a humanidade, não cabendo qualquer alteração que seja repassada para as futuras gerações; quanto às implicações éticas, a modificação da composição natural do ser humano significa o rompimento de um limite que fere o princípio da autodeterminação do indivíduo, ao passo que permite vislumbrar práticas eugenistas e aumento da segregação social. Conclui-se que as possibilidades trazidas pela edição genética através da técnica explorada são inevitáveis e, portanto, cabe ao ordenamento jurídico buscar atualizar-se acerca da sua previsão, tais atualizações devem, sobretudo, considerar os princípios éticos que norteiam a bioética e biodireito. Ressalta-se que pesquisas mais conclusivas deverão nortear tais intervenções.

Palavras-chave: Edição genética, Repercussões, Dignidade da pessoa humana.

\section{INTRODUÇÃO}

A descoberta de meios mais práticos para a edição genética em humanos causou grande alarde no meio científico, sobretudo devido ao anúncio do nascimento dos primeiros humanos geneticamente modificados, fato ocorrido na China, através da utilização da técnica "CRISPR-Cas9"- Clustered Regulary Interepaced Short Palindromic Repeats, que traduzindo para o português significa Sequências Curtas Palindrômicas Agrupadas e Regularmente Espaçadas, o termo faz referência aos fragmentos da fita de DNA. 
A edição genética a partir da técnica CRISPR-Cas9 advém da aplicação das funções desempenhadas por verdadeiros maquinários observáveis no nível molecular, onde se tem a modificação de seguimentos de DNA, segundo Amabis e Martho (2010) O ácido desoxirribonucleico - DNA, é a estrutura que carrega todas as informações hereditárias dos organismos vivos uni ou pluricelulares, sua estrutura em duplahélice é composta por milhares de nucleotídeos unidos sequencialmente cujos seguimentos formam os genes, locais que indicam a expressão das características da cada indivíduo, por exemplo, a cor dos olhos, formato do rosto, inclusive podem comportar anomalias que se expressam em doenças hereditárias.

Deste modo, dominar manipulação genética significa controlar a expressão do genótipo e fenótipo dos organismos, ou seja, sua composição genética e a exteriorização desta. É substancial relatar que os primeiros resultados com a CRISPR-Cas9, mostram-se promissores diante das possibilidades trazidas pela terapia gênica (ORMON et al., 2017).

No entanto, é preciso salientar as divergências presentes no meio científico, pois, não há um consenso a respeito de tais manipulações, posto que algumas pesquisas indicaram efeitos colaterais capazes de resultar em prejuízos como mutações maléficas em outros genes, o aparecimento de cânceres e ainda outras alterações não mensuradas, soma-se a isso o fato de que as mudanças definitivas no DNA impactam as gerações futuras nas suas dimensões biológicas e sociais (CLEMENTE, 2020).

$\mathrm{Na}$ atual conjuntura as incertezas científicas levam a dilemas éticos e legais concernentes a temática, tendo em vista os princípios que norteiam a bioética e o biodireito. No que tange à legislação nacional, verifica-se a regulação das atividades de engenharia genética, por meio da Lei de Biossegurança ( $\left.n^{\circ} 11.105 / 2005\right)$, tal dispositivo veda as práticas de intervenções genéticas envolvendo células germinativas e embriões humanos (BRASIL, 2005). Da mesma forma existe proteção internacional ao patrimônio genético, através de dispositivos visando uma proteção universal ao material genético como unidade fundamental pertencente ao ser humano (UNESCO, 1997). 
Nesse contexto, o presente estudo objetivou investigar de modo as principais repercussões científicas, éticas e legais da edição genética em humanos através da técnica CRISPR-Cas9, a fim de tecer as devidas reflexões acerca do assunto no cenário atual, considerando a proteção ao patrimônio genético em decorrência do princípio da dignidade da pessoa humana. Buscou-se ainda abordar tais aspectos de maneira interdisciplinar, de modo a suscitar o direito conforme perspectivas antropocêntricas.

O presente estudo revela-se de grande importância para o meio acadêmico e social por buscar maiores conhecimentos acerca das nuances envolvidas em um tema polêmico, atual de grande repercussão para o biodireito e áreas afins, como é próprio de um tema multidisciplinar. Trata-se de um assunto envolvendo direitos humanos e fundamentais, a exemplo da dignidade da pessoa humana em face das inovações tecnológicas caracterizadas por mecanismos cada vez mais presentes no mundo pós-moderno e que, portanto, compõem os fatos geradores do direito atual e futuro, cujo dinamismo exige o máximo de atenção e constante deliberação.

Para realização do estudo utilizou-se de pesquisa teórico-bibliográfica integrativa e documental, operacionalizada através da busca de trabalhos acadêmicos em indexadores nacionais e internacionais, sites oficiais de consulta à legislação, bem como livros atualizados, disponíveis no meio físico e digital.

Este trabalho segue uma organização apresentando como resultados e discussões os seguintes eixos temáticos: edição genética; a técnica CRISPR-Cas9; proteção ao patrimônio genético humano; limitações científicas da técnica CRISPR-Cas9 em humanos e as implicações éticas em torno da referida técnica, finalmente a última seção traz as considerações gerais como produto das investigações realizadas. 


\section{DESENVOLVIMENTO}

\subsection{A EDIÇÃO GENÉTICA}

A Engenharia genética possibilita a edição do material genético humano por meio da transferência de sequência gênicas que irão recombinar-se a outros seguimentos de DNA, atividade que necessita do devido controle e regulação para que riscos a vida humana sejam evitados, à medida que se respeite o princípio da dignidade da pessoa humana (MALUF, 2020, p. 59).

As práticas de modificação do organismo através da edição genômica implicam em um melhoramento do mesmo, conferindo-lhe características desejáveis, conforme afirmam Scarmanhã; Silva e Garé:

A engenharia genética realiza processos de manipulações genéticas, objetivando que elementos sejam duplicados, transferidos ou mesmo isolados dos genes originais. Assim, com estes procedimentos, é possível obter seres com genética melhorada com qualidade e aprimoramento de funções (SCARMANHÃ; SILVA; GARÉ, 2019, p. 05).

Nessa dimensão, as aplicações da engenharia genética podem ser realizadas em qualquer organismo animal ou humano, ao que Clemente (2020) assegura, quanto às aplicações da edição genética restringiram-se, inicialmente, às células somáticas, ou seja, células não germinativas, as quais estão presentes na maior parte do corpo humano e diferenciam-se e se especializam em diversos tecidos e órgãos, enquanto as células gaméticas são essenciais para a reprodução de um novo ser. Em síntese, as modificações nas células germinativas podem ser passadas para as gerações futuras, ao contrário, as mudanças nas células somáticas permanecem apenas nos indivíduos que as possui em sua composição.

Diante de tais possibilidades destaca-se o caráter dinâmico das ciências que sempre tende aos avanços, com a engenharia genética não ocorreu diferente, afirma Beriam (2017) que ainda em 2015 começaram a acirrar os debates em torno da alteração genética de células germinativas humanas, ou edição genética de óvulos, 
espermatozoides e embriões (óvulos fecundados), assim, restou a possibilidade de manipular o material genético dos embriões humanos.

Quanto à edição genética em humanos, a legislação pátria tende a proibição de práticas relacionadas, através da Lei de Biossegurança, que estabelece normas para a utilização das técnicas de engenharia genética e liberação de Organismos Geneticamente Modificados - OGMs no meio ambiente (BRASIL, 2005).

Verifica-se a proibição da alteração genética em células embrionárias ou germinativas de seres humanos, através da leitura do artigo $8^{\circ}$ do aludido dispositivo nota-se outras vedações atinentes à manipulação envolvendo células humanas germinais:

Art. 6ำ Fica proibido:

I - Implementação de projeto relativo a OGM sem a manutenção de registro de seu acompanhamento individual;

II - Engenharia genética em organismo vivo ou o manejo in vitro de ADN/ARN natural ou recombinante, realizado em desacordo com as normas previstas nesta Lei;

III - engenharia genética em célula germinal humana, zigoto humano e embrião humano;

IV - Clonagem humana; (...) (BRASIL, 2005).

Vale ressaltar que a citada lei considera crime a aplicação de engenharia genética na edição de células germinativas humanas, prevendo em seu artigo 24 que tal conduta, bem como o qualquer ato de violação ao material genético humano in vivo que não tenha como finalidade a reversão de defeitos genéticos e esteja fora dos ditames legais resultará na pena de detenção de 1 (um) a 3 (três) anos e multa, assim como é penalizada também a clonagem humana e utilização de embrião humano em desacordo com as previsões legais:

Art. 24. Utilizar embrião humano em desacordo com o que dispõe o art. 5을 Lesta Lei:

Pena - detenção, de 1 (um) a 3 (três) anos, e multa. 
Art. 25. Praticar engenharia genética em célula germinal humana, zigoto humano ou embrião humano:

Pena - reclusão, de 1 (um) a 4 (quatro) anos, e multa.

Art. 26. Realizar clonagem humana:

Pena - reclusão, de 2 (dois) a 5 (cinco) anos, e multa.

Art. 27. Liberar ou descartar OGM no meio ambiente, em desacordo com as normas estabelecidas pela CTNBio e pelos órgãos e entidades de registro e fiscalização:

Pena - reclusão, de 1 (um) a 4 (quatro) anos, e multa. (BRASIL, 2005).

Resta clarificado o posicionamento da lei que regula as atividades ligadas alteração genética dos organismos, essa é permitida em outros seres vivos não humanos e em células humanas não embrionárias ou reprodutivas. Em contrapartida a biotecnologia moderna evolve procedimentos de manipulação genética mais polêmicos e revolucionários (REIS; OLIVEIRA, 2019).

Ainda segundo os autores, dentre as técnicas revolucionárias decorrentes das inovações biotecnológicas, mais especificamente no âmbito da engenharia genética destaca-se a técnica de edição gênica denominada CRISPR-Cas9, que permite substituir seguimentos dentro da fita de DNA corrigindo eventuais erros ou falhas genéticas inserindo características desejadas, ou mais benéficas. Tal possibilidade desperta para uma reflexão a respeito dos riscos decorrentes da manipulação do ser humano seguindo seus interesses, a exemplo a possibilidade de práticas eugênicas (REIS; OLIVEIRA, 2019).

\subsection{A TÉCNICA CRISPR-CAS-9}

Segundo Sander e Joung (2014) o sistema CRISPR-Cas9 surgiu a partir de engenharias moleculares do sistema imunológico de bactérias, este viabiliza a edição de qualquer gene através da fragmentação do DNA por uma enzima de restrição chamada "Cas9", a qual é direcionada por um RNA transportador, e tem a capacidade de se parear com sequencias de bases nitrogenadas específicas. 
Corroborando com o mesmo entendimento acima, Boel et al., (2016) compara a técnica a um editor de texto, partindo do ponto de que o DNA é um código escrito, e como qualquer outro pode apresentar erros na sua estrutura, assim como as ferramentas de identificação de erros escritos, a técnica reconhece sequencias específicas de nucleotídeos no DNA-alvo, bem como utiliza meios de recorte para selecioná-los. A figura 3 ilustra como se dá o mecanismo de edição genética através do sistema CRISPR-Cas9.

Figura 3 - Sistema CRISPR - Cas9

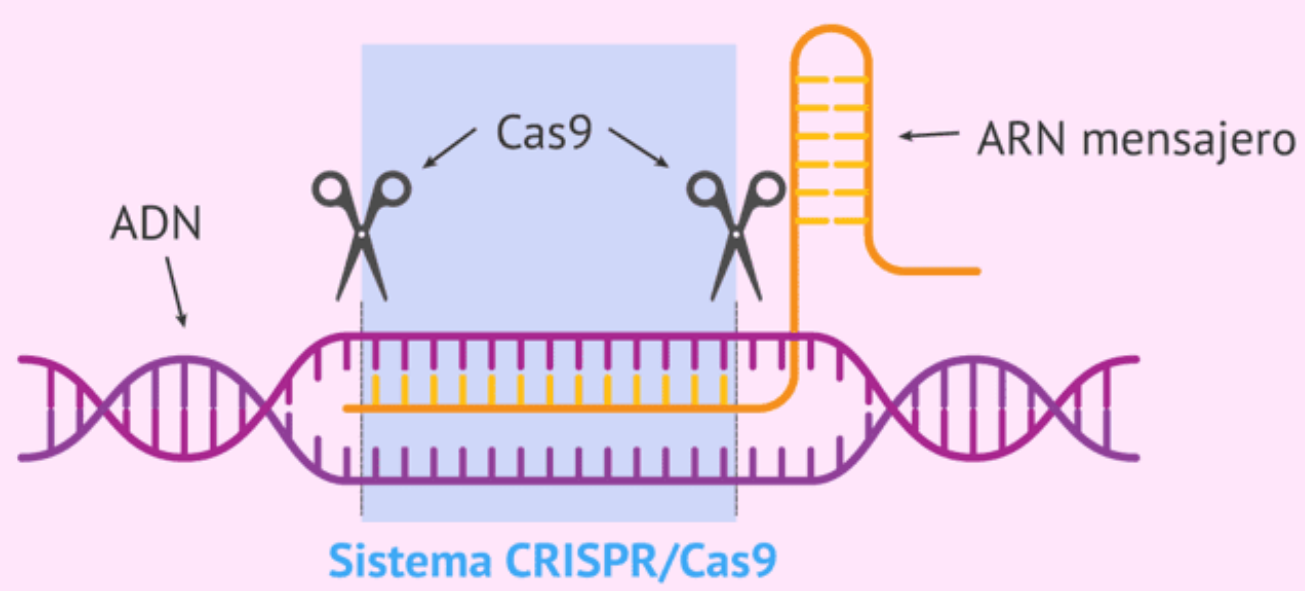

Fonte: Reproducion Asistida ORG (2021).

Nesse contexto Clemente refere-se a dois momentos principais no mecanismo de edição ora comentado, quais sejam, a etapa de reconhecimento e clivagem onde ocorre o corte da molécula de DNA, seguida pela fase de reparo do mesmo, assim:

O processo de edição divide-se em duas etapas, sendo a primeira relacionada ao reconhecimento e clivagem da molécula de DNA e, a segunda, destinada ao reparo da mesma. Uma vez seccionados, os nucleotídeos são acionados mecanismo celulares endógenos, naturais de reparação do DNA. O processo de edição utiliza-se então, desses recursos, para promover modificações pretendidas. Assim, o reparo pode ocorrer por ligação das extremidades não homólogas (mecanismo útil quando se pretende silenciar a ação dos genes) ou também, por reparo dirigido por moldes. Nessa situação, é possível inserir, nas moléculas, juntamente com a ferramenta de edição, moldes de DNA externo. Assim, pode-se fornecer moldes externos contendo genes selecionados, ao novo seguimento de DNA a ser formado no local da clivagem (CLEMENTE, 2020, p. 15). 
Compreende-se que a célula possui mecanismos internos de reparação que são ativados através da ação do sistema CRISPR-Cas9, onde o mesmo se utiliza de tais meios para provocar as mudanças de interesse, estas mudanças podem ocorrer a partir de um molde inserido no processo ou por uso das extremidades já presentes na fita de DNA.

A técnica ora discutida tem se mostrado promissora devido a sua simplicidade, rapidez e eficiência na manipulação genética conforme afirma Clemente (2020), as vantagens desta técnica, representam uma verdadeira revolução no que se refere aos tratamentos de saúde, sobretudo em relação às graves doenças de origem hereditária, as quais muitas vezes são incuráveis. Gera-se, portanto, uma expectativa positiva em relação às novas alternativas terapêuticas.

As aplicações da edição gênica em humanos oferecem muitas vantagens desde pesquisas mais básicas às mais avançadas, possibilitando diversas de melhorias para o ser humano, dentre as inovações podem ser citados: a compreensão sobre a diferenciação celular no processo do desenvolvimento do corpo humano, o funcionamento de genes particulares ainda na fase embrionária do organismo, compreensão sobre doenças de origem genética, proporcionando a produção de fármacos específicos tais patologias, avanços na terapia gênica (tratamento de cânceres), entre outros mecanismos que ainda estão em fase de estudo (CLEMENTE 2020).

Ainda em relação às aplicações, cabe enfatizar sobre a edição genética de crianças recém-nascidas condições de má formação congênita hereditária, pelo menos 6\% das crianças recém-nascidas apresentam sérios problemas de ordem genética, por meio do mecanismo CRISPR-Cas9 identifica-se os seguimentos no DNA que são responsáveis por causas tais patologias, com isso é possível buscar tratamentos preventivos (CLEMENTE, 2020).

Os benefícios aplicam-se ainda a fisiologia do sistema imune. Muitos genes possuem relação direta com a resistência de alguns indivíduos à patógenos causadores de infecções, a identificação destes locais no genoma significa estender 
suas vantagens aos demais organismos e promover uma imunização eficaz. Ressalta-se que tais procedimentos já são realidade (ORMOND et al., 2017).

\subsection{A PROTEÇÃO AO PATRIMÔMNIO GENÉTICO}

Os avanços biotecnológicos são crescentes e vem ganhando cada vez mais espaço, o que infere a necessidade de promover a efetiva proteção ao genoma humano, visando a preservação das futuras gerações (NAVES; GOIATÁ, 2017).

Tal proteção recai sobre temas complexos, uma vez que muitos conflitos surgem, desde interesses econômicos a discussões éticas filosóficas e religiosas, mas a ampla capacidade humana de aplicar os meios tecnológicos para a modificação dos sistemas biológicos requer o devido controle pautado na "regulação e instauração de medidas concretas para a preservação através do uso adequado e consciente dos recursos biológicos" (NASCIMENTO; BRITO, 2021, p. 5).

O patrimônio genético corresponde a toda e qualquer "informação de origem genética de espécies vegetais, animais, microbianas ou de outra natureza, incluindo substâncias oriundas do metabolismo destes seres vivos" (BRASIL, 2015), este conceito foi adotado pela lei 13.123 de maio de 2015, a qual regulamenta a previsão constitucional acerca da preservação da integridade do patrimônio genético, bem como as medidas de proteção e acesso ao patrimônio genético, estabelecidas na Convenção sobre Diversidade Biológica que foi proposta unilateralmente para as nações assinarem durante a Conferência das Nações Unidas Sobre Meio Ambiente e Desenvolvimento em 1992.

Assim, o patrimônio genético é todo e qualquer unidade hereditária presente nos organismos uni ou pluricelulares, e ainda as substâncias resultantes das suas atividades metabólicas. Portanto, a sua proteção recai sobre os genes animais, vegetais de microrganismos, e dos seres humanos. Todavia, a os direitos e obrigações previstos na Lei de Acesso ao Patrimônio Genético não se aplicam ao material humano, conforme redação trazida em seu artigo $4^{\circ}$. 
Assim, a referida norma não contempla regras referentes ao acesso ao patrimônio genético humano. O que se justifica pelas diretrizes e vedações trazidas pela Lei de Biossegurança, cujas proibições incidem sobre condutas envolvendo alteração das células embrionárias, clonagem e qualquer modificação do material genético in vivo em desacordo com as normas vigentes (BRASIL, 2005).

Cabe enfatizar sobre as proibições incidirem em relação à modificações ou manipulação de células embrionárias, ou seja células reprodutivas, todavia, verificase uma lacuna concernente a aplicação de técnicas de modificação genéticas nas células somáticas, as quais através do processo de mitose se diferenciam para formarem os tecidos e demais órgãos humanos. Subtende-se que estando dentro dos padrões e normas reguladoras estas poderão ser submetidas a processos de alteração gênica.

De fato, até poucos anos não se tinham normas regulamentadoras em relação a tais mecanismos, todavia a Agência Nacional de Vigilância Sanitária - Anvisa, regulamentou no ano de 2018, através da RDC $n^{\circ} 260$, as regras para o ensaio clínico dos produtos de terapias avançadas investigacionais, entre as quais se incluem a terapia gênica, segundo a Anvisa (2018) esta tem como produto biológico DNA ou RNA recombinante objetivando a modificação da expressão genética com a finalidade de tratamento terapêutico, preventivo ou de diagnóstico".

Portanto, a terapia gênica realizada em células humanas não reprodutivas passou a ser passível de manipulação, mas a finalidade é exclusivamente de ordem médica, terapêutica que implica em tratamento ou prevenção.

Neste contexto, ressalta-se que a norma regulou tais procedimentos em níveis experimentais "investigacionais" sendo, estes conforme a própria Anvisa (2018) "para fins de comprovação de segurança e eficácia". Todavia, no ano de 2020 a mesma agência registrou a primeira terapia gênica no Brasil para tratamento da Atrofia Muscular Espinhal - AME (NOVARTIS, 2020). 
Considerando que as aplicações biotecnológicas perpassam por entre todos os grupos e reinos de organismos vivos, direciona-se o assunto para a proteção ao material genético humano, que é objeto de proteção nacional por meio das já citadas normas de segurança e internacional através do sistema de proteção aos direitos humanos.

Os direitos humanos são vislumbrados conforme as suas dimensões de proteção, de maneira simples fala-se em direitos de primeira dimensão que protegem as liberdades individuais, direitos de segunda dimensão cuja proteção recai sobre direitos sociais e terceira dimensão relativa aos direitos transindividuais, todavia, uma quarta dimensão passou a prever os direitos relativos aos assuntos de biotecnologia, engenharia genética e suas implicações ético-jurídicas em que pese à conservação da vida humana (GORCZEVSKI, 2009).

Os direitos humanos de quarta geração e sua regulamentação surgiram em decorrência dos novos problemas advindos dos avanços tecnológicos e científicos, que até então não haviam sido enfrentados, no entanto eram perfeitamente previsíveis, especialmente aqueles pertinentes às pesquisas com o genoma humano e sua manipulação (NETO, 1998).

Dessa forma, prevendo as implicações do avanço científico e tecnológico nos assuntos pertinentes à manipulação genética, em 1997 a 29 Conferência Geral da UNESCO adotou o documento proposto pelo Comitê Internacional de Bioética, que foi concebido como a "Declaração Universal do Genoma Humano e dos Direitos Humanos".

A Declaração Universal do Genoma Humano e dos Direitos Humanos objetivou enfatizar a dignidade da pessoa humana em face das pesquisas ligadas a intervenção genética, os direitos dos indivíduos submetidos ao tratamento ou diagnóstico que afetem o seu genoma e estabelecer os limites a serem observados pelas nações que realizam tais pesquisas. Neste contexto, a referida carta aduz que "O genoma humano subjaz à unidade fundamental de todos os membros da família 
humana e também ao reconhecimento de sua dignidade e diversidade inerentes" (UNESCO, 1997).

Dessa forma, a proteção do patrimônio genético proposta pela Unesco, prevê a tutela da individualidade humana, que está em consonância com os aspectos científicos do DNA, haja vista que o material genético é universalmente composto pela mesma estrutura molecular e realiza as mesmas funções fisiológicas, todavia, trata-se de um código único e exclusivo para cada indivíduo. Ainda que carregue informações oriundas dos seus ascendentes, funciona como um texto, descrevendo as características físicas de cada indivíduo. É o que liga toda a família humana, ao passo que confere a originalidade de cada pessoa, como uma impressão digital.

Assim, o dispositivo reconhece o conteúdo genético de cada pessoa é uma herança pertencente a toda a humanidade, cuja diversidade deve ser respeitada e reconhecida, caso contrário, viola-se o princípio da dignidade da pessoa humana, o qual rege toda e qualquer nação alicerçada em um regime democrático. Neste sentido Naves e Goiatá (2017, p. 03) concordam que "a proteção aos dados genéticos humanos é a proteção ao próprio patrimônio genético e à continuidade da espécie em condições dignas".

Corroborando, o aludido dispositivo legal, veda qualquer discriminação em decorrência da composição genética de determinada pessoa de modo que tal violação ocasiona lesão aos direitos humanos e demais liberdades fundamentais (UNESCO, 1997).

Nessa dimensão, o Brasil, em harmonia com as previsões de proteção internacional ao genoma, a carta magna CF/88, no artigo $225 \S 1^{\circ}$ inciso II, incumbiu ao poder público o dever de "preservar a diversidade e a integridade do patrimônio genético do País e fiscalizar as entidades dedicadas à pesquisa e manipulação de material genético" (BRASIL, 1988), a citada previsão legal, no entanto, veio a ser regulamentada com a edição da lei de biossegurança, a qual regula as normas de segurança e instrumentos fiscalizatórios das atividades envolvendo organismos geneticamente modificados - OGM e seus derivados, e cria o Conselho Nacional de 
Biossegurança - CNBS, bem como, reestrutura a Comissão Técnica Nacional de Biossegurança - CTNBio, dispõe sobre a Política Nacional de Biossegurança - PNB (BRASIL, 2005).

\subsection{LIMITAÇÕES DA EDIÇÃO GENÉTICA EM HUMANOS A PARTIR DA TÉCNICA CRISPR-Cas9}

A proteção ao patrimônio genético é muito válida por fazer as devidas previsões mediante as perspectivas da biotecnologia e engenharia genética, desde os mecanismos mais arcaicos de edição genômica até os mais modernos e eficazes abriu-se uma janela para um futuro de grandes descobertas e capacidade de melhorar a vida na terra.

Todavia, deve-se refletir que tal janela é uma espada de dois gumes, à medida que o homem pode usar os recursos científicos para beneficiar o meio ambiente e a saúde humana, também fica sob seu desígnio a alternativa de aplicá-los visando apenas interesses econômicos, sem medir os impactos.

Ainda deve-se verificar 0 fato de não se ter ainda 0 total controle da operacionalização e dos resultados de determinadas técnicas, como se observa no caso da utilização do mecanismo CRISPR-Cas9.

Nesse sentido, as possibilidades decorrentes dos avanços biotecnológicos revolucionaram a maneira de considerar os genes, sobretudo em relação aos aspectos científicos e econômicos, dada a ampliação dos estudos e a valorização do conteúdo genético, agora reconhecido como peça fundamental para os avanços biotecnológicos (NASCIMENTO; BRITO, 2021).

Ainda que a técnica de edição genética a partir do mecanismo CRISPR-Cas9 tenha se mostrado rápida, eficiente e econômica, a literatura relata algumas limitações, o que naturalmente implica em riscos, ou efeitos colaterais. 
Portanto, no contexto científico de onde emergem os experimentos e estudos, verificam-se a apresentação de resultados controversos a respeito das intervenções em relação ao material genético.

Ressalta-se que no campo científico existem dois tipos de controvérsias, quais as internas, decorrentes de questões inconclusivas, incompletas ou demasiadamente complexas; as externas, relacionadas a preocupações, juízos de valor, crenças, concepções religiosas, filosóficas culturais ou éticas (HODSON, 2018). Nessa dimensão discute-se acerca dos resultados inconclusivos ou falhos, que se ligam às incertezas dos experimentos científicos, bem como dos seus impactos, especificamente em relação à edição genética em humanos.

De acordo com Thompson et al., (2019) alguns em experimentos com embriões submetidos à edição genética ocorreu o que pode se chamar de mosaicismo que decorre de um erro no corte do seguimento de interesse, tal erro pode advir de duas possibilidades, corte mal-sucedido pela nuclease (Cas9 que realiza a clivagem), ou devido a reparação incorreta deste. O resultado é a ocorrência de pelo menos três tipos de células, quais sejam, com material genético de origem, as modificadas com mutações e as que foram corretamente alteradas, ou seja, o organismo passa a ter uma composição genética contendo diferentes conjuntos de DNA.

Nesse contexto, relaciona-se tal efeito a uma colcha de retalhos ou mosaico, em alusão a "fragmentação genômica" do organismo. É importante ressaltar a presença de mutação nas células onde não ocorreram os reparos, tem-se que a maioria das mutações são deletérias, ou seja, levam a deficiências congênitas de origem genética, a exemplo de diversas síndromes.

Ressalta-se que havendo o mosaicismo poderá ou não a ocorrer a expressão dos genes indesejáveis, no entanto uma vez presentes na composição do indivíduo ocorre a possibilidade de este serem transferido $s$ para as gerações futuras (CLEMENTE, 2020). 
Outro fator que requer precaução e bastante cuidado é possibilidade de modificações aleatórias "off-tarfegt", são mutações acidentais onde a enzima erra o alvo de corte, ocorrendo por um evento não determinado na Cas9, que leva a ações atípicas e não pretendidas (MARTI-GUITIERREZ et al., 2017).

Diante do exposto Ormond et al. (2017) defendem que tais percalços são pequenos diante da capacidade que a técnica possui de curar de uma infinidade de doenças, cujos efeitos negativos são certos e devastadores. E ainda, o surgimento de resultados imprevistos não é regra, uma vez que o próprio DNA é capaz de suportar um certo nível de mutações.

Infere-se que as manipulações genéticas no DNA humano, não tem apresentado resultados com cem por cento de certeza sobre a aplicação da técnica CRISPRCas9, podendo resultar em prejuízos como mutações maléficas em outros genes, e ainda outras alterações não mensuradas, pois a própria ciência inda não conhece a totalidade dos efeitos da expressão gênica.

Todavia, Ormom et al. (2017) asseveram que em relação a edição de genes in vitro não deve ser alvo de óbices, desde que que esteja sob protocolos éticos jurídicos e de segurança, como autorização dos doadores e supervisão apropriada. É perfeitamente cabível ainda, o financiamento público para tais pesquisas.

Quanto ao prosseguimento das aplicações técnicas em linhagens germinativas humanas com potencial reprodutivo, pelo menos quatro pontos devem ser considerados, quais sejam, "(a) uma justificativa médica convincente, (b) uma base de evidências que apoie seu uso clínico, (c) uma justificativa ética, e (d) um processo público transparente para solicitar e incorporar contribuições das partes interessadas" (ORMON et al., 2017, p. 01).

O referido autor conclui que diante das questões científicas para as quais ainda não se obteve respostas, a edição de genes na linhagem embrionária humana com capacidade de reprodução não deve ser realizada, tais práticas são completamente inadequadas (ORMON et al., 2017). 
Situação contrária ocorreu na China ainda no ano de 2015, onde um grupo de pesquisadores sob supervisão do cientista Junjiu Huang, da Universidade de Sun Yat-sen, conduziram estudos em embriões humanos a partir da técnica CRISPRCas9, objetivando corrigir uma mutação presente no gene HBB, cuja função é codificar a proteína beta-globina (LIANG et al., 2015).

O mais polêmico veio a ocorrer em 2018 com o anúncio do nascimento das gêmeas Lulu e Naná, primeiros seres humanos geneticamente modificados, onde o cientista Jiankui He, usou o mecanismo CRISPR-Cas9 para alterar os genes CCR5, tornar a crianças imunes ao vírus HIV (CÁRDENAS-KRENZ, 2018).

Segundo noticiários o cientista foi condenado pela justiça chinesa, ocasião em que assumiu a programação genética de mais uma criança, dessa forma, mesmo sem existirem normas proibitivas em relação à edição genética de humanos, mas dada a reprovabilidade social, o pesquisador foi condenado a 3 anos de prisão (JUNQUEIRA, 2019).

Sobre tais polêmicas não existe maiores informações, a China é uma nação extremamente fechada. Portanto, não se tem estudos ou notícias de como tais crianças estão, nem de como o terceiro bebê está, se sobreviveu ou apresentou alguma anomalia.

\subsection{IMPLICAÇÕES ÉTICAS EM RELAÇÃO À EDIÇÃO GENÉTICA EM HUMANOS}

No que concerne às implicações éticas, o fracasso/limitações/falhas ou mesmo o sucesso da aplicação da edição genômica a partir da CRISPR-Cas9, geram repercussões (ORMON et al., 2017). Nesse cenário, Sandel (2013, p. 84) alerta para a inevitável existência de dilemas e controvérsias, uma vez que há o avanço tecnológico e científico, mas a evolução da sociedade não acontece no mesmo ritmo. 
Quanto aos aspectos negativos, pondera-se entre a exposição de indivíduos à intervenções com potencial prejudicial em face da incerteza de tais riscos superarem os benefícios, como se dá no caso da edição de embriões humanos, cujos efeitos ainda serão determinados (ORMON et al., 2017).

Um ponto crucial no debate ético refere-se à autonomia dos indivíduos, mesmo diante do êxito da técnica, segundo Ormon et al., (2017) tal tecnologia traz grandes impactos por gerar um ser geneticamente modificado sem o seu consentimento.

Neste ponto, seria necessário considerar que os pais são as pessoas mais apropriadas para decidirem sobre a vida dos filhos, no entanto é assunto polêmico, pois se refere à composição genética de alguém, um ser individual que irá expressar suas características genotípicas e conviver com elas para sempre.

Nessa dimensão Hayden (2016), afirma que os pais, inclusive, já exercem um controle imenso em relação aos filhos, a exemplo da possibilidade de triagem genética durante o pré-natal, onde é possível verificar a ocorrência de anomalias no DNA como é o caso da trissomia 21 - Síndrome de Down, e ainda em relação à escolha de levar ou não uma gestação até o fim, como ocorre em alguns países.

Nesse contexto, tem crescido o número de movimentos contrários a este controle, a exemplo daqueles que consideram a própria concepção um ato imoral, por trazer à existência alguém que jamais pediu para nascer, segundo Benatar (2015, p. 60), principal defensor da ideia, a procriação pode parecer algo inocente, mas é na verdade muito prejudicial, pois uma criança nascida é alvo de todas as mazelas e coisas terríveis que poderão acontecer, embora nem todos venham a sofrer grandes horrores, ninguém está isento de graves danos, a melhor maneira de proteger uma criança das terríveis coisas da vida é não tê-las.

Soma-se a isto o fato de existirem relatos de indivíduos que mesmo possuindo condições genéticas raras e "desvantajosas" como albinismo e nanismo, afirmam que não gostariam de ter seu conteúdo genético alterado para se tornarem pessoas normais (HAYDEN, 2016). 
Há ainda a possibilidade da intervenção pela escolha de genes que expressem condições patológicas, como enuncia Sandel (2013, p. 86), o autor relata o caso de um casal de mulheres surdas, que através da reprodução assistida viabilizaram a concepção de uma criança também surda, tal interesse consistiu na defesa de que a surdez não seria uma condição impeditiva de uma vida como qualquer outra. De fato, a criança nasceu com surdez.

Resta um grande dilema em relação aos limites da edição genética para tratamento de condições tidas como anormais pelo senso comum, conforme Haydem (2016), muitos surdos não consideram sua condição como uma doença ou deficiência, chegando a negar intervenções como implante cocloear e também evitar que seus filhos também surdos sejam submetidos a tratamentos.

Corroborando, Lamphier et al. (2015) pontua que além dos riscos ligados a eugenia, existem os problemas relacionados aos possíveis danos à própria linhagem humana, uma vez que a alteração do material genético implica na transferência hereditária das características, significa a modificação irreversível de um ser humano e seus descendentes.

Além disso, Habermas (2016) acrescenta a preocupação com a autocompreensão ética da espécie, ou seja, os aspectos subjetivos e existenciais da pessoa que foi geneticamente editada sob o juízo de outrem.

O autor supracitado dedicou-se a levantar o questionamento e torno da violação da autodeterminação dos indivíduos, apesar da clara certeza de que um embrião não possui caráter volitivo, o mesmo está em pleno desenvolvimento e irá tornar-se um ser dotado valores, anseios e inversos, nas palavras do mesmo, essa intervenção eugênica "limita a configuração autônoma da vida do indivíduo e mina as relações fundamentalmente simétricas entre pessoas livres e iguais" (HABERMAS, 2016, p. 15).

Verifica-se neste processo biotecnológico um claro e notável conflito com os propícios da bioética, entre os quais podem ser citados, o princípio da autonomia, 
segundo Maluf (2020, p. 155) relaciona-se a capacidade de autogovernança dos indivíduos. A interferência nos genes de embriões aptos para reprodução significaria, dentro dos limites éticos e legais brasileiros, a violação do referido princípio.

Outro princípio "sob a mira" da edição genética é da própria dignidade da pessoa humana, para Maluf (2020, p.155) este em harmonia com o princípio da sacralidade, preveem a proteção da vida humana em toda a sua dimensão.

Nesse diapasão é importante discutir sobre a controvérsia em torno do surgimento da personalidade, que segundo Venosa (2007, p. 230) no ordenamento jurídico brasileiro ela é útil para suscitar os direitos de cada indivíduo, sobre este tema irradiam divergências em torno do nascituro.

Tal polêmica persiste devido à leitura trazida pelo artigo $2^{\circ}$ do Código Civil de 2002, onde afirma que a personalidade de uma pessoa se inicia mediante no nascimento com vida, no entanto a lei resguarda os direitos do nascituro, (BRASIL, 2002). Sobre tais pontos, ressalta-se que se trata de direitos na esfera civil, enquanto a lei põe a salvo qualquer direito do nascituro.

Todavia, a definição de nascituro não se enquadra no que é ainda apenas um embrião, pois o ser concebido e não nascido corresponde ao embrião após a nidação, ou seja, após fixação na parede interna do útero. Assim, não se fala em direitos relativos ao embrião, todavia, Tartuce (2015) pontua a importância de a legislação abrigar a previsão acerca de tais tecnologias.

Nesse diapasão Cervi questiona,

(...) diante das inovações biotecnológicas de edição genética embrionária, seria possível promover uma interpretação acerca de intimidade e identidade e dos direitos da personalidade em um momento até mesmo anterior ao nascimento com vida, ou antes, à própria consideração de ser o embrião nascituro? (CERVI, 2019, p. 13). 
Em meio a tal lacuna o autor defende uma (re)significação dos dispositivos legais conforme as inevitáveis demandas modernas a fim de proteger o consagrado princípio da dignidade da pessoa humana (CERVI, 2019).

Depreende-se que os valores éticos e culturais são relativos a cada povo e nação, ao passo que a essência humana e composição humana é una, nesse sentido, Rodotá (2010) aduz a respeito da possibilidade de edição de embriões humanos que receber um corpo físico desenhado conforme determinação de alguém avilta contra os direitos do homem.

\subsubsection{QUESTÕES RELACIONADAS À EUGENIA}

O vislumbre e encantamento diante das perspectivas de cura a partir da edição genética transformam-se em preocupação, inclusive, diante das eventuais interferências visando interesses escusos, baseados em aspectos culturais, considerando que o controle da técnica seja utilizado na escolha de características físicas, como altura, cor dos olhos, cabelos, formato do rosto etc. (CERVI, 2019).

Assim, as preocupações se voltam para os riscos de práticas eugênicas, considerando o interesse do ser humano por aqui que é belo e distante do anormal ou feio, para Cervi (2019) o desejo pela beleza e juventude sempre acompanhou o homem, sendo prova disso, sua necessidade de expressar a perfeição em obras de artes, bem como é verificado nas narrativas literárias ao descrever características de personagens jovens e atraentes.

De maneira, simples, a eugenia consiste na seleção de indivíduos a partir de suas características genéticas com o intuito de aprimorar os descendentes que irão nascer. Em relação a edição genética Ormon et al. (2017) alerta para a possibilidade de esta ser usada para a seleção de características que vão além de interesses terapêuticos.

Para Bobbio (2016) o conceito desenvolvido na Inglaterra no Século XIX, equipa-se as teorias da hereditariedade de biológicas raciais e a interpretação subversiva da 
seleção natural proposto por Charles Darwin, segundo a qual o mais adaptado sobrevive, ou seja, aquele com características genéticas melhores irá sobreviver. Segundo o doutrinador, tais teorias originaram práticas erroneamente aplicadas em contextos políticos racistas: onde se pregava a purificação racial.

Consoante a tal observação, Ormon et al., (2017) sob qualquer um dos aspectos, a eugenia é uma prática perigosa, ao reforçar preconceitos a partir da definição do que seria normal, ou aceitável na sociedade, como ocorreu historicamente, o aperfeiçoamento do DNA humano, sem o objetivo terapêutico associou-se a uma determinação genética, que apoiada pelo estado gerou consequências desastrosas.

Portanto a o melhoramento genético nunca deve ser usado para reforçar o preconceito de estereótipos, sobretudo, conhecendo o que a crença na supremacia de uma raça pode causar, a exemplo do que ocorreu na Alemanha Nazista, onde se acreditou que a raça Ariana por ser superior as outras deveria dominar, a este respeito Cervi (2019, p.05) afirma "a pretensão de limpeza étnica e de promoção da raça pura e de beleza ariana, gerou ao seu revés, muita tristeza, exclusão, miséria e morte, além de sentimentos de vergonha".

Assim, possibilidade de práticas eugênicas gera preocupações em torno de uma possível seleção de indivíduos e suas características como um padrão determinante, o que geraria uma perda da diversidade humana.

\subsubsection{IMPLICAÇÕES SOCIAIS}

Dentro dos impasses éticos da edição genética humana, cabe discutir brevemente em torno das implicações sociais no possível cenário de indivíduos cujas características foram previamente escolhidas e determinada artificialmente.

Notadamente a técnica é restringida a protocolos que impedem sua aplicação, mas numa possível realidade em que se tem regulação da sua implementação, Ormon et al. (2017) alertam que o as consequências sociais são uns dos pontos mais 
importantes, diante do sucesso pois é provável que torne ainda maior as desigualdades sociais já enfrentadas atualmente.

Ressalta-se que mesmo os procedimentos de saúde um pouco mais complexos são muitas vezes restritos a quem pode dispor de boas quantias, a exemplo da reprodução assistida, de acordo com Cervi (2019) os procedimentos biotecnológicos de aplicação na área da saúde são possíveis a um grupo pequeno de pessoas, sendo que não existem perspectivas em torno de um amplo acesso às melhores terapias curativas.

Cabe, portanto, o questionamento de Singer (2017, p.135) "o que acontecerá para quem não tem dinheiro para ir ao supermercado genético? Ficarão seus filhos predestinados à mediocridade?"

Seguramente cada pessoa busca o melhor para si e para o seus, sabe-se que o ser humano não mede esforços para buscar aquilo que lhe confere qualidade de vida e segurança. O que antes parecia utópico, hoje não é tão distante, mas quanto aos já marginalizados o futuro permanece repleto de incertezas.

De acordo com Singer (2017) nessa lógica, o mercado de genes poderia favorecer aqueles com maior poder aquisitivo a inserir na linhagem genética dos seus descendentes genes codificadores de características que podem favorecer a inteligência, aptidão para prática de determinados esportes, entre outros (SINGER, 2017). O autor cita ainda a exclusão da "loteria genética" para se referir aos possíveis impactos causados pela escolha artificial de qualidades desejáveis.

\section{CONSIDERAÇÕES FINAIS}

O presente estudo objetivou trazer uma abordagem interdisciplinar pontuando as principais repercussões científicas, ético-filosóficas e jurídicas trazidas pela edição genética em humanos a partir da técnica Crispr-Cas9, tal mecanismo biotecnológico de engenharia genética abriu novos precedentes em relação ao tratamento e 
combate de patologias humanas até então tidas como instransponíveis. Assim, vislumbra-o como uma tecnologia inevitável na pós-modernidade.

Todavia, um universo de possibilidades decorre da aplicação da manipulação genética através do sistema CRISPR-Cas9, o que pôs em alerta a comunidade científica, uma vez que este se mostra eficaz, acessível e rápido, mas os experimentos ainda trazem outros resultados inconclusivos diante de eventuais erros no desempenho da ferramenta, podendo culminar em efeitos imprevisíveis e deletérios para o organismo.

Preocupa-se ainda com o uso de finalidades escusas como melhoramento genético humano, prática veementemente reprovada por suscitar ideais eugenistas, os quais, no passado, levaram a verdadeiros desastres sob a justificativa da crença em raças superiores.

Considerando a clara dificuldade do ser humano em obedecer aos limites necessários para o uso equilibrado dos recursos Ambientais, visando o Meio Ambiente ecologicamente equilibrado. Verificou-se inquietações a respeito da desigualdade social que uma técnica da tal magnitude pode causar, posto que tais procedimentos certamente serão exaustivamente caros, levando a mais segregação entre humanos cujos pais puderam pagar por características e predisposições genéticas desejáveis versus humanos concebidos sob a loteria genética.

Dentre os assuntos relativos a proteção jurídica que orbitam ao redor do tema, temse que a composição genética de cada indivíduo é um patrimônio de toda a família humana, conforme prevê organizações de proteção internacional, que o considera um bem inviolável, essencial para manutenção do princípio da dignidade da pessoa humana, jamais podendo ser utilizado para fins segregacionistas.

A proteção ao patrimônio genético também se projeta em nível nacional, no sentido de proibir quaisquer manipulações envolvendo o material genético humano, como procedimentos envolvendo clonagem e embriões humanos. Interpreta-se que a proibição recai sobre as técnicas de edição relativas ao sistema CRISPR-Cas9. 
Cabe um destaque para a recente regulação de terapia gênica em nível experimental, cuja responsabilidade reguladora cabe à Agência Nacional de Vigilância Sanitária - Anvisa.

Diante do futuro com inevitável aperfeiçoamento e aprimoramento dos mecanismos biotecnológicos, resta uma necessidade jurídico-normativa concernente a tais práticas, atentando-se para as considerações da bioética, enquanto matéria que busca os estabelecer os meios corretos para aplicação de procedimentos envolvendo o Meio Ambiente e saúde humana, consolidando cada vez mais o Biodireito e os princípios que o regem.

\section{REFERÊNCIAS}

AGÊNCIA NACIONAL DE VIGILÂNCIA SANITÁRIA - ANVISA. Resolução da Diretoria Colegiada - RDC № 260, de 21 de Dezembro de 2018. Dispõe sobre as regras para a realização de ensaios clínicos com produto de terapia avançada investigacional no Brasil, e dá outras providências. Disponível em:< https://www.in.gov.br/materia/-

/asset_publisher/Kujrw0TZC2Mb/content/id/57218930/do1-2018-12-28-resolucao-dadiretoria-colegiada-rdc-n-260-de-21-de-dezembro-de-2018-57218634> Acesso em 17 jun 2021.

AMABIS, J. M.; MARTHO, G. R. Biologia das células. v. 1. São Paulo: Moderna, 2010.

BOBBIO, N. Dicionário de Política. Brasília: Universidade de Brasília, 2016.

BRASIL. Constituição da República Federativa do Brasil de 1988. Disponível em: < http://www.planalto.gov.br/ccivil_03/Constituicao/Constituicao.htm>. Acesso em 28 jan 2021.

BRASIL. Lei № 11.105, de 24 de Março de 2005. Disponível em:< http://www.planalto.gov.br/ccivil_03/_Ato2004-2006/2005/Lei/L11105.htm>. Acesso em 28 jan 2021. 
BRASIL. Lei $n^{\circ}$ 13.123, de 20 de maio de 2015. Regulamenta o inciso II do $\S 1^{\circ} \mathbf{e}$ o § 4 do art. 225 da Constituição Federal, o Artigo 1, a alínea j do Artigo 8, a alínea c do Artigo 10, o Artigo 15 e os $\S \S 3^{\circ}$ e $4^{\circ}$ do Artigo 16 da Convenção sobre Diversidade Biológica, promulgada pelo Decreto no 2.519, de 16 de março de 1998; dispõe sobre o acesso ao patrimônio genético, sobre a proteção e o acesso ao conhecimento tradicional associado e sobre a repartição de benefícios para conservação e uso sustentável da biodiversidade; revoga a Medida Provisória no 2.186-16, de 23 de agosto de 2001; e dá outras providências. Brasília, 20 de maio de 2015. Disponível em:< http://www.planalto.gov.br/ccivil_03/_ato2015-2018/2015/lei//13123.htm> Acesso em 16 jun 2021.

BRITO, N. B. V., Nascimento, S. M. C. Herança da vida: reflexões ético-jurídicas acerca do Patrimônio Genético. Brasil, Editora Dialética, 2021.

BOEL, Annekatrien et al. BATCH-GE: Batch analysis of Next-Generation Sequencing data for genome editing assessment. Scientific reports, v. 6, n. 1, p. 1-10, 2016. Disponível em:< https://www.nature.com/articles/srep30330>. Acesso em 01 jun 2021.

CERVI, T. M. D. Dorian Gray Na Moldura Do Século Xxi: Reflexões Jurídicas Em Edição Genética Embrionária. RJLB, Ano 5 (2019), no 3. Disponível em:< http://www.cidp.pt/revistas/rjlb/2019/3/2019_03_1703_1721.pdf> Acesso em 19 jun 2021.

CLEMENTE, G. T. Avanços e desafios na edição gênica em seres humanos. In NICOLETI, C. E. et al. Biodireito, Bioética e Filosofia em Debate. Almedina, São Paulo. 2020.

Conferência Geral da Organização das Nações Unidas para a Educação, Ciência e Cultura (UNESCO) 29. aㅗ sessão. Declaração Universal do Genoma Humano e dos Direitos Humanos. 11 de novembro de 1997. 
GORCZEVSKI, C. Direitos humanos, educação e cidadania: conhecer, educar, praticar. Santa Cruz do Sul: Edunisc, p. 16, 2009.

HABERMAS, J. O futuro da natureza humana. Tradução de Karina Jannini. $2^{\underline{a}}$ ed. São Paulo: WMF Martins Fontes, 2016.

HAYDEN, C. E. Should you edit your children's genes?. Nature News, v. 530, n. 7591, p. 402, 2016.

HODSON, D. Realçando p papel da ética e da política educação científica. In: Dália Melissa Conrado, Nei Nunes-Neto. Questões sociocientíficas: fundamentos, propostas de ensino e perspectivas para ações sociopolíticas. Brasil, Editora da Universidade Federal da Bahia, 2018.

JUNQUEIRA, D. China confirma o nascimento de terceiro bebê geneticamente modificado. Olhar Digital. $\quad$ Disponível em:< https://olhardigital.com.br/2019/12/31/ciencia-e-espaco/china-confirma-nascimentode-terceiro-bebe-geneticamente-modificado/> Acesso em 19 jun 2021.

LAMPHIER, E. et al. Don't edit the human germ line. Nature, v. 519, p. 410-411, mar. 2015. Disponível em:< https://www.nature.com/news/don-t-edit-the-human-germ-line1.17111 > Acesso em: 03 de mai 2021.

MALUF, A. C. R. F.D. Curso de bioética e biodireito. 3ª ed. Atlas. São Paulo. 2015.

NAVES, B. T. O.; GOIATÁ, S. R. Direitos Humanos, patrimônio genético e dados genéticos humanos: crítica à doutrina dos dados genéticos como interesse difuso. Revista de bioética y derecho, n. 40, p. 63-81, 2017.

NETO, F. V. L. Direitos humanos de 4ª Geração. DHNET, 1998. Disponível em < http://www.dhnet.org.br/direitos/textos/geracaodh/4_geracao.html> Acesso em 22 de mai de 2021. 
NOVARTIS. Aprovado o registro da primeira terapia gênica para AME no Brasil. 18 Agosto 2020. Disponível em:< https://www.novartis.com.br/news/aprovado-oregistro-da-primeira-terapia-genica-para-ame-no-brasil> acesso em 17 jun 2021.

ORMOND, K. E. et al. Human germline genome editing. The American Journal of Human Genetics, v. 101, n. 2, p. 167-176, 2017.

REIS, É. V. B.; OLIVEIRA, B. T. Crispr-Cas9, Biossegurança E Bioética Uma Análise Jusfilosófica-Ambiental da Engenharia Genética. Veredas do Direito: Direito Ambiental e Desenvolvimento Sustentável, v. 16, n. 34, p. 123-152, 2019.

RODOTÁ, Stefano. La vida y las reglas: entre el derecho y el no derecho. Traduzido por Andrea Greppi. Madrid: Edi-torial Trotta, 2010.

SCARMANHÃ, B. O. S. G. SILVA, M. F. GARÉ, C. C. T. Os avanços biotecnológicos e da engenharia genética: sob a perspectiva da reprodução humana assistida e seus reflexos no direito de família. RJLB, Ano 5 (2019). Disponível em:< http://www.cidp.pt/revistas/rjlb/2019/3/2019_03_0259_0279.pdf> Acesso em 11 jun 2021.

SANDEL, M. Contra a perfeição: ética na era da engenharia genética. Rio de Janeiro: Civilização Brasileira, 2013.

SANDER, J. D.; JOUNG, J. Keith. CRISPR-Cas systems for editing, regulating and targeting genomes. Nature biotechnology, v. 32, n. 4, p. 347, 2014.

SINGER, P. Ética no mundo real: 82 breves ensaios sobre coisas realmente importantes. Traduzido por Desidério Murcho. Lisboa: Edições 70, 2017.

TARTUCE, F. Manual de Direito Civil. Vol. Único. $5^{\mathrm{a}}$ Edição. Editora Método. São Paulo. 2015. 
THOMPSON, Deborah J. et al. Genetic predisposition to mosaic $Y$ chromosome loss in blood. Nature, v. $575, \quad$ n. 7784 , p. 652-657, 2019. Disponível em:< https://www.nature.com/articles/s41586-019-1765-3> Acesso em: 18 jun 2021.

VENOSA, S. S. Direito Civil-Parte Geral. 7 ed. São Paulo (SP): Atlas, 2007.

Enviado: Setembro, 2021.

Aprovado: Setembro, 2021. 